\title{
Erkinis encefalitas: studentų požiūrio ir turimų žinių analizè
}

\author{
R. Mineikyte்* \\ G. Navickaitė* \\ J. Valaikiené ${ }^{* *}$ \\ *Vilniaus universiteto \\ Medicinos fakultetas \\ **Vilniaus universiteto \\ Medicinos fakulteto \\ Klinikines medicinos instituto \\ Neurologijos ir neurochirurgijos \\ klinika, Neurologijos centras
}

\begin{abstract}
Santrauka. I vadas. Nustatyta, kad sergamumas erkiniu encefalitu (EE) Lietuvoje $2016 \mathrm{~m}$. padvigubejjo ir yra vienas didžiausių Europoje. Šio tyrimo tikslas išsiaiškinti ir ịvertinti I-IV kursų medicinos studentų požiūrị ir žinias apie EE sergamumą Lietuvoje, riziką susirgti, komplikacijas, gydymą, naudojamas prevencijos priemones ir informacijos apie erkiu platinamų ligų sklaidą.

Tiriamieji ir tyrimo metodai. Atlikta anoniminè anketinè apklausa, kurioje dalyvavo 404 studentai, besimokantys Vilniaus universiteto Medicinos fakulteto I-IV kursuose (amžius vid. $-20,7 \pm 1,56 \mathrm{~m} ., 17-30 \mathrm{~m}$.). Anketą sudare 21 pusiau uždaras klausimas: 6 klausimai apie EE sergamumą, komplikacijas ir gydymą, 9 klausimai apie erkių platinamų ligų prevencines priemones ir 2 klausimai apie informacijos šaltinius ir sklaidac.

Rezultatai. EE, kaip erkių platinamą ligą, ịvardijo 397 (98,3 \%), Laimo boreliozę (LB) $382(94,6 \%)$ respondentai. Kad sergamumas EE Lietuvoje didelis (> 11/100 tūkst. gyv. per metus), žinojo $58(14,4 \%)$ studentai, 159 (39,4 \%) atsakè, kad vidutinis (2-10/100 tūkst. gyv. per metus). Dažniausios ịvardintos EE komplikacijos buvo paralyžius, parezè 327 (80,9 \%). Efektyviausia prevencijos priemone 237 (58,7 \%) studentai įvardijo skiepus. Pasiskiepijusių nuo EE buvo 169 (41,8 \%). Teigiančių, kad galimas tik simptominis gydymas, buvo 106 (26 \%). 113 (28,0 \%) studentų nuomone, žmonės apie erkių platinamas ligas yra pakankamai informuoti, o $193(47,8 \%)$ manè, kad dėmesio skiriama per mažai. $219(54 \%)$ studentų pagrindiniu šaltiniu apie EE ịvardijo žiniasklaidą.

Išvados. Tik 14,4 \% studentų žinojo, kad sergamumas EE Lietuvoje yra didelis, o ne vidutinis. Beveik visi sutiko, kad EE sukelia ilgalaikių komplikacijų, bet tik kas ketvirtas žinojo, kad gydymas yra tik simptominis. Dauguma studentų atsakè, kad vakcinacija yra efektyviausia prevencijos priemonè, beveik pusè respondentų nurodè, kad yra pasiskiepiję nuo EE. Kas antras studentas teigè, kad visuomenè nèra pakankamai informuota apie erkių platinamas ligas.
\end{abstract}

Raktažodžiai: erkinis encefalitas, erkinio encefalito virusas, sergamumas, vakcinacija, prevencija.

\section{IVADAS}

Erkinis encefalitas (EE) - tai gamtinè židininė infekcija, kurią sukelia erkinio encefalito virusas (EEV) [1]. EEV priklauso Flavivirus genčiai, ji perneša Ixodes genties erkès [2]. Yra išskiriami trys viruso potipiai - Europos, Sibiro ir Tolimujų Rytų [3]. EE klinikiniai simptomai pasireiš-

\author{
Adresas: \\ Rüta Mineikytè \\ Vilniaus universiteto Medicinos fakultetas \\ M. K. Čiurlionio g. 21, LT-03101 Vilnius \\ El.paštas ruta.mineikyte@gmail.com
}

kia nuo 1 iki 3 savaičių po kontakto su erke [4]. EE būdinga dvifazè ligos eiga - pradžioje vyrauja ị gripą panašūs simptomai: karščiavimas, raumenų skausmas, nuovargis ir galvos skausmas, trunkantys apie 4 dienas (1-8 dienos). Antrajai fazei būdingi CNS pažeidimo požymiai: galvos skausmas, irzlumas, meninginiai simptomai, ataksija, tremoras, kognityvinè disfunkcija (negalejimas sukoncentruoti dèmesio, atminties sutrikimai, disfazija), galvinių nervų paralyžius [5]. Specifinio gydymo nėra, galima taikyti tik simptomus mažinančią terapiją [6]. EE yra viena sunkiausių neurologinių ligų [7], tačiau egzistuoja efektyvios vakcinos nuo EE [3]. Per pastaruosius dešimtmečius stebimas didelis sergamumo padidejimas ne tik Lietuvoje,

(C) Neurologijos seminarai, 2018. Open Access. This article is distributed under the terms of the Creative Commons Attribution 4.0 International License CC-BY 4.0 (http://creativecommons.org/licenses/by/4.0/), which permits unrestricted use, distribution, and reproduction in any medium, provided you give appropriate credit to the original author(s) and the source, provide a link to the Creative Commons license, and indicate if changes were made. 
bet ir pasaulyje [8]. İvairiose Europos šalyse EE sergamumo rodikliai padidejo nuo 2 iki 17 kartų [9]. Šiuo metu EE yra endeminis 27 Europos šalyse [10]. 2015 m. Lietuvoje sergamumas EE buvo 12 atvejų 100 tūkst. gyventojų per metus - užregistruota 336 EE atvejai, o 2016 m. sergamumas EE padvigubëjo - užregistruota 632 atvejai [11].

\section{TYRIMO TIKSLAS}

Išsiaiškinti ir įvertinti I-IV kursų medicinos studentų požiūrị ir žinias apie EE sergamumą Lietuvoje, riziką susirgti, komplikacijas, gydymą, naudojamas prevencijos priemones ir informacijos apie erkių platinamų ligų sklaidą. Šie rezultatai svarbūs dèl panašių tyrimų trūkumo Lietuvoje.

\section{TIRIAMIEJI IR TYRIMO METODAI}

Tiriamieji. Tyrimas vykdytas $2016 \mathrm{~m}$. gruodžio - $2017 \mathrm{~m}$. vasario mèn. Jame dalyvavo 404 Vilniaus universiteto Medicinos fakulteto studentai (289 moterys, 115 vyrų). Jų amžiaus vidurkis - 20,7 $\pm 1,56$ m., 17-30 m. I ir II kursų studentų - 233 (57,7 \%), III ir IV kursų - 171 (42,3\%).

Tyrimo metodai. Buvo atlikta anoniminė anketinė apklausa, kurią sudarė 21 pusiau uždaras klausimas. Dalis klausimų neturẻjo pateiktų atsakymo variantų, todèl tyrèjai nedarè įtakos respondentų nuomonei. Tyrejjai sukūrẻ 14 anketos klausimų, kiti - parengti pagal čekų ir lenkų mokslininkų atliktą tyrimą [12]. Klausimyną sudarė demografiniai klausimai (lytis, amžius), 6 klausimai apie EE sergamumą, komplikacijas ir gydymą, 9 klausimai apie erkių platinamų ligų prevencines priemones ir 2 klausimai apie informacijos šaltinius bei sklaidą.

\section{REZULTATAI}

EE, kaip erkių platinamą ligą, įvardijo 397 (98,3 \%), Laimo boreliozę (LB) - 382 (94,6 \%) respondentai (1 lentelè). Kitas erkių platinamas ligas - tuliaremiją, babeziozę, anaplazmozę, erlichiozę - i̇vardijo $10(2,5 \%)$ studentų. Dauguma apklaustujų nesirgo erkių platinamomis ligomis: $7(1,7 \%)$ respondentai persirgo LB, vienas iš jų - ir EE, tačiau ị klausimą, ar turi artimaji, kuris yra sirgęs šiomis ligomis, $92(22,8 \%)$ apklaustieji atsakè teigiamai.

Apklausti 283 (70,0\%) respondentai manè, kad EE daug komplikacijų sukelianti liga, $83(23,5 \%)$ respondentai teigè, kad tai yra mirtina liga, ir $131(32,4 \%)$ atsake, kad EE pavojingumas priklauso nuo išorinių aplinkybių. 190 (47 \%) respondentų teigè, kad, įkandus erkei, rizika susirgti EE visada yra didelè.

Tyrimo metu taip pat buvo siekiama išsiaiškinti studentų žinias apie EE sukeliamas komplikacijas. Dažniausios įvardintos EE komplikacijos buvo paralyžius,
1 lentelè. Atsakymai ị klausimus apie EE

\begin{tabular}{|c|c|}
\hline & $\mathbf{N}(\%)$ \\
\hline \multicolumn{2}{|l|}{ Kokias erkių platinamas ligas žinote? $(\mathrm{N}=404)$} \\
\hline Erkinis encefalitas & $397(98,3)$ \\
\hline Laimo boreliozė & $382(94,6)$ \\
\hline Kita liga & $10(2,5)$ \\
\hline \multicolumn{2}{|l|}{ Kokia rizika susirgti EE įkandus erkei? $(\mathrm{N}=404)$} \\
\hline Visada didelè & $190(47)$ \\
\hline Priklauso nuo išorinių aplinkybių & $141(34,9)$ \\
\hline Maža rizika & $69(17,1)$ \\
\hline Nèra & $4(1)$ \\
\hline \multicolumn{2}{|l|}{ Ar erkinis encefalitas yra pavojinga liga? $(\mathrm{N}=404)$} \\
\hline Taip & $403(99,8)$ \\
\hline $\mathrm{Ne}$ & $1(0,2)$ \\
\hline \multicolumn{2}{|l|}{$\begin{array}{l}\text { Kokias erkinio encefalito komplikacijas žinote?* } \\
(\mathrm{N}=404)\end{array}$} \\
\hline Paralyžius, parezė & $327(80,9)$ \\
\hline Psichikos sutrikimai & $252(62,4)$ \\
\hline Sutrikusi judesių koordinacija & $253(62,6)$ \\
\hline Susilpnèjusi klausa & $108(26,7)$ \\
\hline Atminties, dèmesio, miego sutrikimai & $216(53,5)$ \\
\hline Dirglumas & $169(41,8)$ \\
\hline Nuolatinis galvos skausmas & $192(47,5)$ \\
\hline Kita & $29(7,2)$ \\
\hline Komplikacijų nesukelia & $3(0,7)$ \\
\hline \multicolumn{2}{|l|}{$\begin{array}{l}\text { Koks sergamumas erkiniu encefalitu Lietuvoje? } \\
(\mathrm{N}=404)\end{array}$} \\
\hline Didelis (> 11/100 tūkst. gyv. per metus) & $58(14,4)$ \\
\hline Vidutinis (2-10/100 tūkst. gyv. per metus) & $159(39,4)$ \\
\hline Mažas (<2/100 tūkst. gyv. per metus) & $43(10,6)$ \\
\hline Nežinau & $144(35,6)$ \\
\hline \multicolumn{2}{|l|}{ Kaip gydomas erkinis encefalitas?* $(\mathrm{N}=404)$} \\
\hline Gydymo nereikia, praeina savaime & $2(0,5)$ \\
\hline $\begin{array}{l}\text { Tik laiku pradèjus gydyti galima pasveikti } \\
\text { Nesvarbus gydymas, lieka negrižtami }\end{array}$ & $184(45,5)$ \\
\hline sveikatos pokyčiai & $36(8,9)$ \\
\hline Specifinio gydymo nèra, tik simptominis & $106(26,2)$ \\
\hline Nežinau & $95(23,5)$ \\
\hline
\end{tabular}

* I I klausimus pasirinkti keli atsakymai.

parezè - 327 (80,9\%). Taip pat minimi psichikos sutrikimai - $252(62,4 \%)$, sutrikusi judesių koordinacija $253(62,6 \%)$ atsakymai. Susilpnėjusią klausą, kaip EE komplikaciją, ịvardijo 108 (26,7 \%) studentai.

Kad sergamumas EE Lietuvoje didelis (> 11/100 tūkst. gyventojų per metus), teigė $58(14,4 \%)$ studentai, iš jų didžioji dauguma buvo IV kurso (32,3\%) studentai. $159(39,4 \%)$ respondentai atsakè, kad sergamumas yra vidutinis (2-10/100 tūkst. gyventojų per metus). Manančių, kad EE sergamumas mažas (<2/100 tūkst. gyventojų per metus), buvo 43 (10,6 \%). Likę $144(35,6 \%)$ studentai atsakymo nežinojo.

Tyrime taip pat klausta apie EE gydymą. Dauguma $184(45,5 \%)$ apklaustieji - manè, kad, tik laiku pradèjus gydyti, galima pasveikti, $36(8,9 \%)$ studentai teigè, kad nepriklausomai nuo gydymo vis tiek išlieka negričžtamų sveikatos pokyčių. Galvojančių, kad galimas tik simptominis gydymas, buvo $106(26,2 \%)$. 
2 lentelè. Atsakymai i klausimus apie prevencijos priemones

\begin{tabular}{|c|c|}
\hline & $\mathbf{N}(\%)$ \\
\hline \multicolumn{2}{|l|}{ Ar saugotès nuo erkių įkandimo? $(\mathrm{N}=404)$} \\
\hline Taip & $339(83,9)$ \\
\hline $\mathrm{Ne}$ & $51(12,6)$ \\
\hline Kita & $14(3,5)$ \\
\hline \multicolumn{2}{|l|}{$\begin{array}{l}\text { Kokiomis priemonėmis saugotės nuo erkių } \\
\text { ịkandimo?* }(\mathrm{N}=404)\end{array}$} \\
\hline $\begin{array}{l}\text { Nesilankote vietose, kuriose didelis erkių } \\
\text { paplitimas }\end{array}$ & $213(52,7)$ \\
\hline Vengiate aukštos žolès, krūmais apaugusių & \\
\hline $\begin{array}{l}\text { vietoviü } \\
\text { Dèvite apsauginius drabužius }\end{array}$ & $\mid \begin{array}{l}239(59,2) \\
280(69,3)\end{array}$ \\
\hline Naudojate repelentus & $329(81,4)$ \\
\hline Vartojate B grupès vitaminais praturtintą maistą & $46(11,3)$ \\
\hline Esate pasiskiepiję nuo erkinio encefalito viruso & $169(41,8)$ \\
\hline Grižę iš rizikingos vietos, nusiprausiate po dušu & $231(57,2)$ \\
\hline Atliekate kūno patikrą & $342(84,6)$ \\
\hline Vartojate tik termiškai apdorotą pieną & $88(21,8)$ \\
\hline \multicolumn{2}{|c|}{ Kuri iš šiu priemoniu yra veiksmingiausia?* $(\mathrm{N}=404)$} \\
\hline $\begin{array}{l}\text { Nesilankymas vietose, kuriose didelis erkių } \\
\text { paplitimas }\end{array}$ & \\
\hline Vengimas aukštos žolès, krūmais apaugusiu & $90(22,3)$ \\
\hline vietovių & $49(12,1)$ \\
\hline Apsauginiai drabužiai & $44(10,9)$ \\
\hline Repelentai & $48(11,9)$ \\
\hline B grupès vitaminais praturtinto maisto vartojimas & $5(1,2)$ \\
\hline Skiepijimasis nuo erkinio encefalito viruso & $237(58,7)$ \\
\hline Nusiprausimas po dušu, grižus iš rizikingos vietos & $10(2,5)$ \\
\hline Kūno patikra & $75(18,6)$ \\
\hline Termiškai apdoroto maisto vartojimas & $3(0,7)$ \\
\hline \multicolumn{2}{|l|}{ İvardinkite nesiskiepijimo nuo EE priežastị $(\mathrm{N}=235)$} \\
\hline Vakcina neefektyvi & $7(3)$ \\
\hline Papildomos finansinès išlaidos & $79(33,6)$ \\
\hline Laiko stoka & $79(33,6)$ \\
\hline Bijau skiepų, jų šalutinio poveikio & $5(2,1)$ \\
\hline Kita & $65(27,7)$ \\
\hline \multicolumn{2}{|c|}{ Pagal kokius kriterijus renkatès repelentus?* $(\mathrm{N}=329)$} \\
\hline Kaina & $115(34,9)$ \\
\hline Efektyvumas & $227(69)$ \\
\hline Toksiškumas, poveikis sveikatai & $65(19,8)$ \\
\hline Ipakavimo dizainas & $17(5,2)$ \\
\hline Kita & $29(8,8)$ \\
\hline \multicolumn{2}{|l|}{ Kuriems repelentams teikiate pirmenybę? $(\mathrm{N}=329)$} \\
\hline Natūralaus pagrindo & $107(32,5)$ \\
\hline Sintetinio pagrindo & $14(4,3)$ \\
\hline Nesvarbu & $208(63,2)$ \\
\hline \multicolumn{2}{|l|}{ Kokiomis repelentų rūšimis naudojatės?* $(\mathrm{N}=329)$} \\
\hline Purškiklis & $301(91,5)$ \\
\hline Kremas & $47(14,3)$ \\
\hline Skystis & $28(8,5)$ \\
\hline Kietas tepalas & $8(2,4)$ \\
\hline Kita & $15(4,6)$ \\
\hline \multicolumn{2}{|l|}{ Ar saugu repelentus naudoti vaikams?* $(\mathrm{N}=404)$} \\
\hline Saugu & $90(22,3)$ \\
\hline Nesaugu & $15(3,7)$ \\
\hline $\begin{array}{l}\text { Priklauso nuo veikliosios medžiagos kiekio ir } \\
\text { sudetties }\end{array}$ & $243(60,1)$ \\
\hline Priklauso nuo vaiko amžiaus & $106(26,2)$ \\
\hline Kita & $20(5)$ \\
\hline
\end{tabular}

* İ klausimus pasirinkti keli atsakymai.
Kita dalis klausimų buvo apie erkių platinamų ligų prevencijos priemones (2 lentelè). Dažniausia prevencijos priemone ịvardinta kūno apžiūra grịžus iš vietos, kurioje buvo rizika erkei įkąsti - tokị atsakymą pasirinko 342 studentai (84,6 \%). $280(69,3 \%)$ studentų pažymėjo, kad dėvi apsauginius drabužius, $329(81,4 \%)$ studentai naudoja repelentus. Renkantis repelentus, 227 studentams (69 \%) svarbiausias kriterijus buvo efektyvumas, 115 (34,9\%) respondentų - jų kaina. Dauguma - 156 (63,2 \%) studentai - teigè, kad jiems nesvarbu, ar repelentas yra natūralaus, ar sintetinio pagrindo, $301(91,5 \%)$ respondentas dažniausiai naudojama repelentų rūšimi įvardijo purškiklį. $243(60,1 \%)$ respondentai manè, kad repelentų naudojimas vaikams priklauso nuo veikliosios medžiagos kiekio ir sudéties. Paklausus apie tradicines medicinos priemones erkių platinamų ligų prevencijai, 9 studentai ịvardijo ciberžolès, čiobrelių eterinius aliejus ir česnaką, taip pat minejjo actą, gvazdikų aliejų, citrinų sultis, medų.

Skiepus nuo EE, kaip efektyviausią prevencijos priemonę, įvardijo 237 (58,7 \%) studentai (59,2 \% moterų, $57,4 \%$ vyrų). Iš visų apklaustujų $169(41,8 \%)$ teigè, kad yra pasiskiepiję nuo EE (39,7 \% moterų, 47 \% vyrų). Daugiausia pasiskiepijusių buvo I kurso studentų - $46 \%$, mažiausiai - ketvirtakursių - 34,3\%. Nepasiskiepijusių studentų paprašyta įvardinti priežastis: $79(33,6 \%)$ atsakè, kad neturi laiko (34 \% moterų, $21 \%$ vyrų), $79(33,6 \%)$ respondentai (32\% moterų, $42,1 \%$ vyrų) teigè, kad nenori turėti papildomų finansinių išlaidų.

Klausimynu buvo bandoma išsiaiškinti, ar Lietuvoje pakankamai dėmesio skiriama visuomenès informavimui apie erkių platinamas ligas (3 lentelè). 113 (28,0 \%) studentų nuomone, žmonès yra pakankamai informuoti, 193 (47,8 \%) manè, kad dėmesio skiriama per mažai. Studentai pagrindiniu informacijos šaltiniu įvardijo žiniasklaidą - $219(54,2 \%), 144(35,6 \%)$ apklaustieji informaciją gauna iš mokslinès literatūros. Draugus ir artimuosius, kaip informacijos šaltinį, ịvardijo $141(34,9 \%)$ respondentas.

Paskutiniame anketos klausime buvo prašoma respondentų įvertinti savo turimas žinias pagal dešimties balų sis-

3 lentelè. Atsakymai i klausimus apie informacijos šaltinius ir sklaidą

\begin{tabular}{||l|c|}
\hline \hline & N (\%) \\
\hline $\begin{array}{l}\text { Ar pakankamai dėmesio skiriama siekiant } \\
\text { informuoti žmones apie erkių platinamas ligas } \\
\text { ir prevenciją Lietuvoje? (N = 404) }\end{array}$ & \\
$\quad$ Taip & \\
Ne & $113(30)$ \\
Nesidomiu & $193(47,8)$ \\
\hline Iš kur gaunate informacijos apie erkių & $98(24,3)$ \\
platinamas ligas?* $(\mathrm{N}=404)$ & \\
Mokslinė literatūra & \\
Žiniasklaida & $144(35,6)$ \\
Draugai, artimieji & $219(54,2)$ \\
Nesidomiu & $141(34,9)$ \\
Kita & $49(12,1)$ \\
\hline \hline
\end{tabular}

* I klausimus pasirinkti keli atsakymai. 
temą (pav.). 9-10 balais įvertino 18 (4,5\%), 7-8 balais 139 (34,4 \%), 5-6 balais savo žinias ívertino 169 (41,8 \%) studentai. Mažiau nei 5 balais ịvertino 78 (19,3\%) respondentai.

\section{APTARIMAS}

Šia apklausa tirtas skirtingas studentų požiūris ir žinios apie kiekvienais metais vis didejjančią visuomenès sveikatos problemą - erkių platinamas ligas, ypač didelị dėmesi skiriant EE. Europoje yra nedaug tyrimų, kurių tikslas būtų ištirti ir įvertinti visuomenès žinias apie šias ligas [12, 13]. Lietuvoje atliktos tik kelios tokio pobūdžio apklausos [14].

Šiame tyrime dalyvavo tikslinè visuomenès dalis - medicinos studentai. Jų atsakymai vertinti pagal lytị ir kursą, norint išsiaiškinti, ar požiūris ir žinios skiriasi tarp vyrų ir moterų, tarp skirtingų kursų studentų. Didžioji dauguma studentų ívardijo Lietuvoje labiausiai paplitusias erkių platinamas ligas - EE ir LB, tačiau tik keli respondentai paminėjo kitas ligas: erlichiozę, tuliaremiją, babeziozę, anaplazmozę. Šiuo metu, dažniau keliaujant, žmonėms yra svarbu laiku pastebėti ir atpažinti erkès įkandimą, net ir būnant kitoje šalyje. Gydytojas privalo žinoti ne tik apie EE, LB, bet ir apie kitų ligų riziką, kad, pasireiškus ligos simptomams, būtų pasirinktas tinkamas gydymo būdas [15].

Didžioji dalis respondentų teisingai ịvardijo EE simptomus ir komplikacijas. Tik 26,2 \% apklaustujų atsake, kad specifinio gydymo nėra, taikoma simptominè terapija. Taip pat studentai nežinojo apie EE sergamumą Lietuvoje: tik $14,4 \%$ respondentų ịvardijo, kad jis yra didelis (> 11/100 tūkst. gyventojų per metus), dauguma manè, kad sergamumas - vidutinis (2-10/100 tūkst. gyventojų per metus).

Sprendžiant iš apklausos rezultatų, galima daryti prielaidą, kad Lietuvoje studentai saugosi nuo erkių įkandimų - $78 \%$ vyrų ir $86 \%$ moterų teigè, kad naudoja prevencines priemones. Kūno patikra yra populiariausias studentų profilaktikos būdas - jị įvardijo 84,6\% studentų (88\% moterų, $77 \%$ vyrų). Butler ir kt. atliktame tyrime ši būdą pasirinko $67 \%$ apklaustųjų [15], o Nejezchlebová ir kt. tyrime rezultatas svyruoja nuo $4 \%$ (Lenkijos universiteto vyrai) iki $89 \%$ (Čekijos universiteto moterys) [13]. Nors ankstyvas erkès ištraukimas apsaugo nuo LB, tačiau rizikai susirgti EE tai įtakos neturi [12]. Vis dèlto literatūroje atsiranda vis daugiau priešingų nuomonių, teigiančių, kad ankstyvas erkès ištraukimas taip pat gali sumažinti riziką susirgti EE [16, 17].

Kitas dažnas profilaktikos nuo erkių platinamų ligų būdas yra apsauginių drabužių dèvėjimas, kurị pasirinko 69,3\% tyrime dalyvavusių lietuvių studentų, Čekijoje ir Lenkijoje šis būdas naudojamas rečiau (33-50 \%) [13], o Suomijoje $61 \%$ apklaustụjų teigė dažniausiai dėvintys šviesių spalvų, ilgų rankovių drabužius, kelnes [12]. Repelentus naudojo $81,4 \%$ šio tyrimo respondentų. Suomijoje atliktame tyrime jie naudojami rečiau - $15 \%$ apklaustųju atsake, kad repelentus naudoja kartais, o tik $5 \%$ - visada [12]. Tyrimo Suomijoje autoriai teigè, kad šioje šalyje vy-

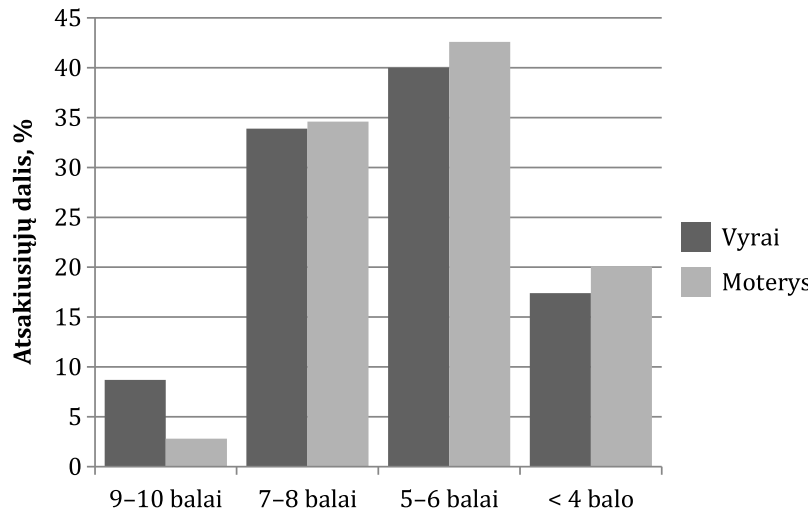

Pav. Atsakymas ị klausimą apie savo žinių apie EE ịvertinimą balais

rauja neigiamas požiūris ị repelentų efektyvumą, nors jų naudojimą rekomenduoja Suomijos visuomenès sveikatos institutas [12]. Čekijoje ir Lenkijoje repelentai naudojami taip pat rečiau nei Lietuvoje (33-65 \%) [13]. Renkantis repelentus, Lietuvos, Čekijos ir Lenkijos studentams svarbiausias yra jų efektyvumas, populiariausia rūšis - purškiklis [13]. Lietuviams studentams kitas kriterijus buvo kaina (36 \% vyrų, $31 \%$ moteru). Didesnis skirtumas tarp demografinių grupių išryškejjo kalbant apie repelentų natūralumą - tik maža dalis čekų ar lenkų studentų rinktųsi sintetinị produktą, o net dviem trečdaliams apklaustų lietuvių nebuvo svarbu, kokios kilmės yra repelentas (66\% vyrų, $63 \%$ moterų) [13]. Dauguma Lietuvoje atlikto tyrimo studentų nurodè, kad repelentai yra saugūs vaikams, tačiau saugumas priklauso nuo veikliosios medžiagos ir kiekio. Tačiau ir čekai, ir lenkai nurode, kad repelentai vaikams yra netinkami [13].

Kita svarbi problema, aptariama atliktame tyrime, yra vakcinacija. Dauguma studentų vakciną nuo EE įvardijo kaip efektyviausią priemonę, pasiskiepiję beveik pusė studentų (41,8 \%). Šio tyrimo rezultatas panašus su Suomijoje atlikto tyrimo duomenimis, vakcinuota $40 \%$ respondentu [12]. Šis rezultatas yra dvigubai didesnis nei Lenkijoje (22 \%) ir daug didesnis nei Čekijoje (4 \%) [13]. Remiantis Lietuvoje atliktu tyrimu, svarbiausios priežastys nesiskiepyti buvo laiko stoka (42 \% vyrų, $32 \%$ moteru) ir papildomos finansinès išlaidos (37 \% vyrų, $34 \%$ moterų).

Galima teigti, kad studentų žinios apie erkių pernešamas ligas yra pakankamos, tačiau respondentai, paprašyti įvertinti savo žinias, manè kitaip. Dažniausias įvertis 5-6 balai (41,8\%), o 9-10 balais įsivertino tik 4,5\% studentų. Taip pat net $47,8 \%$ studentų teigè, kad visuomenès informavimui apie erkių platinamas ligas ir prevenciją Lietuvoje yra skiriama nepakankamai demesio. Studentai dažniausiu informacijos šaltiniu rinkosi žiniasklaidą $(54,2 \%)$. Šio tyrimo išskirtinumas yra tai, kad tirta tikslinẻ visuomenès dalis, kuri yra mokoma apie erkių pernešamas ligas, prevenciją ir kurios žinios bei požiūris nebūtinai atitinka visuomenėje vyraujančią nuomonę ir žinias. Dėl šios priežasties svarbu atkreipti dẻmesi i i šio tyrimo rezultatus, yra rekomenduojamas tolimesnis platesnis ir išsamesnis visuomenès tyrimas. 


\section{IŠVADOS}

1. Remiantis šio tyrimo duomenimis, galima teigti, kad tik 14,4\% apklaustų studentų žinojo, kad sergamumas EE Lietuvoje yra didelis, o ne vidutinis.

2. Beveik visi sutiko, kad EE sukelia ilgalaikių komplikacijų, bet tik kas ketvirtas žinojo, kad gydymas yra tik simptominis.

3. Dauguma studentų manè, kad vakcinacija yra efektyviausia prevencijos priemonè, beveik pusė respondentų yra pasiskiepiję nuo EE.

4. Kas antras studentas teigè, kad visuomenè nèra pakankamai informuota apie erkių platinamas ligas.

\section{Literatūra}

1. Valarcher J, Hägglund $\mathrm{S}$, Juremalm $\mathrm{M}$, et al. Tick-borne encephalitis. Rev Sci Tech 2015; 34(2): 453-66. https://doi.org/10.20506/rst.34.2.2371

2. Süss J. Tick-borne encephalitis 2010: epidemiology, risk areas, and virus strains in Europe and Asia - an overview. Ticks Tick Borne Dis 2011; 2(1): 2-15. https://doi.org/10.1016/ j.ttbdis.2010.10.007

3. Lindquist L, Vapalahti O. Tick-borne encephalitis. Lancet 2008; 371(9627): 1861-71. https://doi.org/10.1016/S01406736(08)60800-4

4. Bogovic P, Lotric-Furlan S, Strle F. What tick-borne encephalitis may look like: clinical signs and symptoms. Travel Med Infect Dis 2010; 8(4): 246-50. https://doi.org/10.1016/ j.tmaid.2010.05.011

5. Holzmann H. Diagnosis of tick-borne encephalitis. Vaccine 2003; 21(Suppl 1): 36-40. https://doi.org/10.1016/S0264410X(02)00819-8

6. Mickienè A, Laiskonis A, Günther G, et al. Tickborne encephalitis in an area of high endemicity in Lithuania: disease severity and long-term prognosis. Clin Infect Dis 2002; 35(6): 650-8. https://doi.org/10.1086/342059

7. World Health Organization. Vaccines against tick-borne encephalitis: WHO position paper. Wkly Epidemiol Rec 2011; 86: 241-56.

8. Radzišauskienė D, Žagminas K, Ašoklienè L, et al. Epidemiological patterns of tick-borne encephalitis in Lithuania and clinical features in adults in the light of the high incidence in recent years: a retrospective study. Eur J Neurol 2018; 25(2): 268-74. https://doi.org/10.1111/ene.13486

9. European Centers for Disease Prevention and Control. Annual epidemiological report 2014 - emerging and vector borne diseases. Stockholm: ECDC, 2014.

10. Amicizia D, Domnich A, Panatto D, et al. Epidemiology of tick-borne encephalitis (TBE) in Europe and its prevention by available vaccines. Hum Vaccin Immunother 2013; 9(5): 1163-71. https://doi.org/10.4161/hv.23802

11. Užkrečiamujų ligų ir AIDS centras. Sergamumo užkrečiamosiomis ligomis Lietuvoje 2015 m. apžvalga. 2016.

12. Nejezchlebová H, Kiewra D, Žákovská A, et al. Students' attitudes to tick risks. Ann Agric Environ Med 2016; 23(3): 437-41. https://doi.org/10.5604/12321966.1219183

13. Zöldi V, Turunen T, Lyytikäinen O, et al. Knowledge, attitudes, and practices regarding ticks and tick-borne diseases. Ticks Tick Borne Dis 2017; 8(6): 872-7. https://doi.org/ 10.1016/j.ttbdis.2017.07.004

14. Vaitkevičiūtė R, Vèlyvytė D, Radvilavičienė J, et al. Kauno medicinos universiteto Visuomenès sveikatos fakulteto studentų žinios apie erkių pernešamas ligas ir požiūris ị erkinio encefalito profilaktiką. Visuomenès sveikata 2009; 2(45): 45-73.

15. Butler A, Sedghi T, Petrini J, et al. Tick-borne disease preventive practices and perceptions in an endemic area. Ticks Tick-Borne Dis 2016; 7(2): 331-7. https://doi.org/10.1016/ j.ttbdis.2015.12.003

16. Charrel R, Attoui H, Butenko A, et al. Tick-borne virus diseases of human interest in Europe. Clin Microbiol Infect 2004; 10(12): 1040-55. https://doi.org/10.1111/j.14690691.2004.01022.x

17. Donoso-Mantke O, Karan L, Růžek D. Tick-borne encephalitis virus: a general overview. In: Růžek D, ed. Flavivirus encephalitis. Rijeka: InTech, 2011; 133-56.

\section{R. Mineikytè, G. Navickaitė, J. Valaikienė}

\section{TICK-BORNE ENCEPHALITIS: STUDENTS' ATTITUDE AND KNOWLEDGE ANALYSIS}

\section{Summary}

Background. Lithuania is one of the countries with the highest incidence of TBE in Europe. In 2015 there were 12 cases per 100000 people per year and in 2016 this number was higher by two times. The aim of this study is to investigate and evaluate I-IV year medical students' attitude and knowledge of TBE incidences in Lithuania, risk of getting it, complications, treatment, preventive methods and behaviour, and information sources about tick-borne diseases.

Materials and methods. The study was conducted using an anonymous questionnaire, which was administered to $404 \mathrm{stu}-$ dents studying at I-IV year medical courses (average age $20.7 \pm 1.56$, range from 17 to 30 years). The questionnaire consisted of 21 semi-closed questions. There were 6 questions about TBE, its incidence, complications and treatment, 9 questions about preventive methods of tick-borne diseases, and 2 questions about information sources and information accessibility.

Results. TBE as a tick-borne disease was named by $397(98.3 \%)$ students and as Lyme borreliosis was named by $382(94.6 \%)$. The fact that TBE incidence in Lithuania is high (>11 cases per 100000 per year) was known only to $58(14.4 \%)$ respondents, 159 (39.4\%) answered that the incidence is medium (2-10 cases per 100000 per year). The most commonly named complications of TBE were paralysis and paresis - $327(81 \%)$ students. 3 respondents (1\%) thought that TBE is a disease without any complications. The most effective preventive method, chosen by $237(58.7 \%)$ students, was vaccination. There were $169(41.8 \%)$ vaccinated students. $106(26 \%)$ students thought that there are no specific treatment for TBE, only supportive care. The fact that people are well enough informed about tick-borne diseases was supported by 113 (28\%) students, and 193 (47.8\%) students thought that there is lack of information. $219(54 \%)$ students named media as the main source of information.

Conclusions. Only $14.4 \%$ of students knew that TBE incidence in Lithuania is high, not medium. Almost all of them agreed that TBE causes long term complications but only one of four knew that there is no specific, only supportive care. The majority of students think that vaccination is the most effective preventive method and almost half of students were vaccinated against tick-borne encephalitis. Every second student thinks that society is not enough informed about tick-borne diseases.

Keywords: tick-borne encephalitis, tick-borne encephalitis virus, incidence, vaccination, prevention.

Gauta:

Priimta spaudai:

20180418 20180511 